\title{
DEFLECTION CONTROL IN RCC BEAMS BY USING MILD STEEL STRIPS (AN EXPERIMENTAL INVESTIGATION)
}

\author{
Asif Reyaz ${ }^{1}$, Mohmad Mohsin Thakur ${ }^{2}$, Ali $^{3}$, Ishtiyak Ahmad ${ }^{4}$ \\ ${ }^{1}$ Bachleor of Technology, Civil Engineering Department, NIT Srinagar, $J \& K$, India \\ ${ }^{2}$ Bachleor of Technology, Civil Engineering Department, NIT Srinagar, $J \& K$, India \\ ${ }^{3}$ Bachleor of Technology, Civil Engineering Department, NIT Srinagar, J\&K, India \\ ${ }^{4}$ Bachleor of Technology, Civil Engineering Department, NIT Srinagar, $J \& K$, India
}

\begin{abstract}
It is well recognised that in modern practice, structural failures are all too common in terms of Serviceability and are relatively rare in terms of Safety. Adoption of limit state of design and higher grades of concrete and steel in modern RCC structures has led to overall thinner member sections and high stress levels at service loads. These in turn have resulted in larger deflections, crackwidths, vibrations etc. In particular, it is the Serviceability Limit state of 'Durability' that calls for particular attention, because 'Deflection' is a very important criteria need to be taken into account. Due to architectural constrain generally depth of beams are restricted, that leads to more deflection in a beam. An attempt has been made through this project to check the feasibility and efficiency of Mild Steel sheets used as a composite material with traditional RCC beams to modify its serviceability criteria. MS Sheets are used due to their economy, durability and are also easily available in large variety of cross-sections (gauges). MS sheets also have the property of being cast to any shape without much need of significant formwork. The composite construction has an edge over the conventional reinforced concrete material because of its ease of construction, thinner sections as compared to RCC, efficient bonding with concrete due to its large surface area \& high tensile strength (per unit weight) which makes it a favourable material for prefabrication also. The ill effect of corrosion is reduced here as the MS Strips are embedded into the concrete material, thus less prone to exposure and also has no aesthetic issues. Extra care can be taken by providing coating also. The main aim of this project is to increase the stiffness of beam in order to control the deflection. Mild steel sheets and strips of varying thickness (gauges) were embedded into traditional RCC beam vertically along side faces in longitudinal direction. This increases both moment of inertia as well as modulus of elasticity of beam, thus increasing its stiffness and controlling deflection. The test results are compared and it has been observed that deflection is controlled by about $30 \%$ and strength is increased by about $25 \%$ in MS-strip composite beams as compared to control beam.
\end{abstract}

Keywords: composite beam, limit state of design, MS-sheets, Deflection, Stiffness, Moment of inertia, flexural member etc...

\section{INTRODUCTION}

An important and economic combination of construction materials is that of steel and concrete. The concept of composite construction has been adopted in this project to control deflection and to check failure due to serviceability. In this section we are providing the background details of this method and what are our prime objectives. Serviceability limit state of design is to be adopted, which is the guiding factor to check deflection, cracking, vibration, durability, etc.

\subsection{Background}

A modern composite construction concept was initially developed in North America and is now used extensively all over the world and it has been further developed and redefined. It achieves important benefits by making steel and concrete work together. It is powerful construction concept in which compressive strength of concrete and tensile strength of steel are almost effectively used. Steel and concrete have almost same thermal expansion apart from an ideal combination of structure. Hence, these essentially different materials are completely compatible and complimentary to each other. The composite action provides resistance to imposing load and more importantly improves the stiffness of the member. It has several advantages over traditional reinforced concrete or steel structures; these include high strength to weight ratio, structural integrity, dimensional stability etc. These advantages lead to a substantial increase in the use of composite construction.[9]

\subsection{Objective}

The main objective is to explore innovative construction technology where steel strips act compositely with surrounded concrete.

The aim of this project is to;

- Increase the stiffness of flexural member (shallow beam) in order to control deflection.

- $\quad$ Reduce cross section of member for both aesthetic and economical view-point. 


\section{DESIGN PHILOSOPHY}

Over the years various design philosophies have been evolved in different parts of the world, with regard to reinforced concrete design. A 'design philosophy' is built up on a few fundamental premises and is reflective of a way of thinking Limit state of design is to be used which is the most widely used method in the world. It aims for a comprehensive and rational solution to design problem, by considering safety at ultimate loads and serviceability at working loads. Ultimate limit state also known as limit state of collapse deals with strength, overturning, sliding, buckling, fatigue fracture etc and serviceability limit state deals with discomfort to occupancy and malfunction, caused by excessive deflection, crack-width, vibration, leakage and also loss of durability.

Serviceability limit state is to be satisfied in the design, because it causes many problems such as ;

- $\quad$ Aesthetic/ Psychological discomfort.

- Crack width formation.

- Ponding in roof or slab.

- Reduces structural integrity

- Excessive vibration

\section{Types of Deflection}

a) Short-term Deflection: (Due to applied service load): If the applied bending moment is less than cracking moment, than the full uncracked section provides the rigidity and the moment of inertia for the gross section $\left(\mathrm{I}_{\mathrm{g}}\right)$. But when applied moment is greater than cracking moment, different size tension cracks occur and the position of neutral axis varies. The position of a beam where the applied moment is less than cracking moment $\left(\mathrm{M}_{\mathrm{cr}}\right)$, is assumed to be uncracked and moment of inertia can be assumed $\mathrm{I}_{\mathrm{g}}$. When applied moment is greater than $\mathrm{M}_{\mathrm{cr}}$, tensile cracks that develop in the beam will ineffectively cause the beam cross section to reduce and moment of inertia is assumed to be equal to $\mathrm{I}_{\mathrm{cr}}$.

The IS code has given the moment of inertia that is used for deflection calculation .This moment of inertia is called as Effective Moment of Inertia( $\left.\mathrm{I}_{\mathrm{eff}}\right)$

$$
\mathrm{I}_{\mathrm{eff}}=\mathrm{I}_{\mathrm{cr}} /\left\{\mathrm{I} \cdot 2-\left(\mathrm{M}_{\mathrm{cr}} / \mathrm{M}\right) \mathrm{n}\right\}
$$

$\mathrm{n}=\mathrm{z}(1-\mathrm{k}) \mathrm{b}_{\mathrm{w}} / \mathrm{db}$

$b_{w}=$ breadth of web.

$\mathrm{b}=$ breadth of compression face.

Stiffness trend:

$$
\mathrm{EI}_{\mathrm{T}}>\mathrm{EI}_{\mathrm{gr}}>\mathrm{EI}_{\mathrm{eff}}>\mathrm{EI}_{\mathrm{cr}}
$$

b) Long-term Deflection: (Due to sustained load) Long term load further increases the deflections because of shrinkage and creep that is the function of age of concrete, percentage of compression steel, temperature etc. Both creep and shrinkage depend on the amount of concrete. Therefore introduction of MS-sheet helps in minimizing the effect of creep and shrinkage [10]
To overcome the above drawback of deflection and to increase the $\mathrm{I}_{\text {eff }}$ and reduce the effect of creep and shrinkage, MS-sheets are introduced. Test results are analyzed to check the effect of MS-strips on the beam.

\subsection{Design of a Beam}

Limit state of design was adopted for the design of control beam. The internal resisting forces were calculated at some assumed load and the theoretical behavior of control beam was studied [4]

\section{Assumptions}

a) Plane section normal to beam axis remain plane after bending.

b) Maximum compressive strain in concrete shall be taken as 0.0035

c) Tensile strength of concrete is ignored.

d) The strain in tension reinforcement at the ultimate limit state shall not be less than $(0.87 \mathrm{fy} / \mathrm{Es})+0.002$

\section{Design Results}

a) Effective span $=1.75 \mathrm{~m}$

b) Cross section $=(100 \times 150) \mathrm{mm}, \mathrm{d}_{\text {eff }}=130 \mathrm{~mm}$

c) Characteristic strength of concrete $=20 \mathrm{MPa}$ (nominal mix)

d) Assumed load $=20 \mathrm{KN}$

e) Applied moment (2-point load) $=5.87 \mathrm{KNm}$

f) $\mathrm{Mu}$ (limiting) $=4.69 \mathrm{KN}$

g) Re-bars ( Fe-415) : 2-10ф diameter bars at bottom \& 2$8 \phi$ diameter bar at top.

h) Shear stirrups: $6 \phi$ bars at a spacing of $100 \mathrm{~mm}$.

\subsection{Arrangement of Steel in Beams}

$8 \phi$ and $10 \phi$ bars were used for tensile and compression reinforcement respectively. $6 \phi$ stirrups were used for shear reinforcement. MS strips were embedded in concrete material vertically in cross-section along axial direction, to increase the stiffness of beam

\section{Specimen:}

A beam of nominal mix M-20 ( $1: 1.5: 3)$ with dimensions ' $100 \mathrm{~mm} \times 150 \mathrm{~mm}$ ' and effective span of $1.75 \mathrm{~m}$ reinforced with steel bars and MS-sheets. 


\subsubsection{Control Beam}
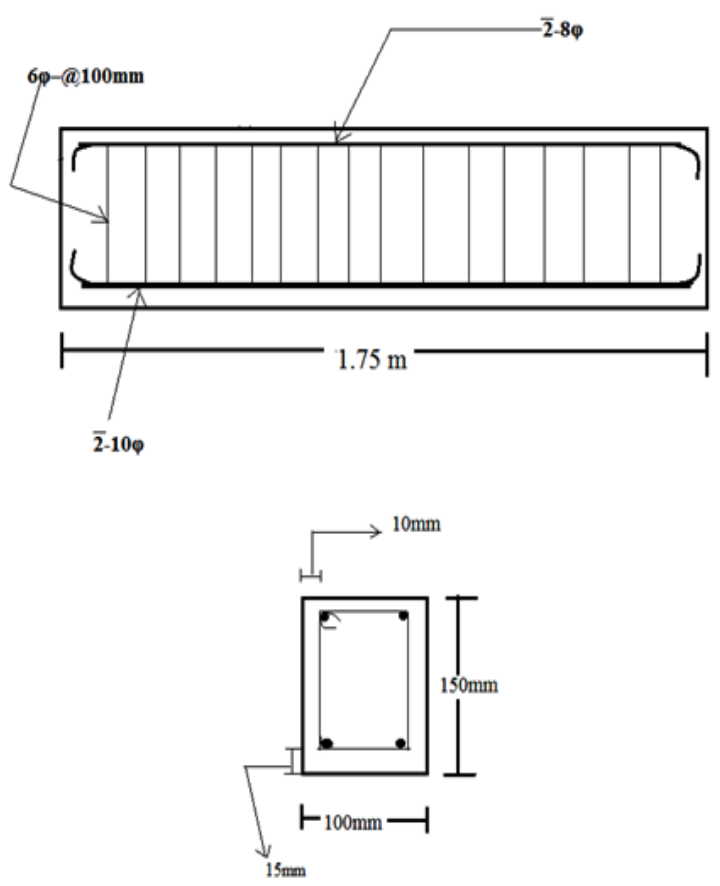

Fig-1: Normal RCC beam

\subsubsection{Beam with MS-Strips provided in Full Depth}

\section{Axially}
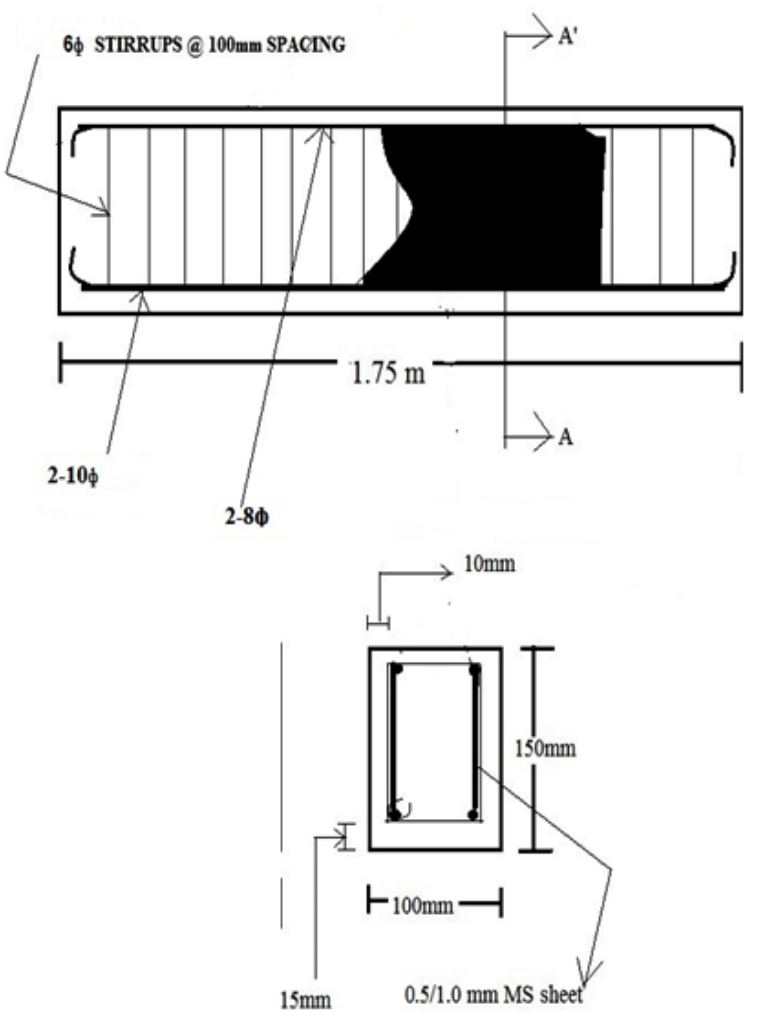

Fig-2: Composite RCC beam with MS-strips on full face

\subsubsection{Beam with MS-Strips above and below Neutral Axis}
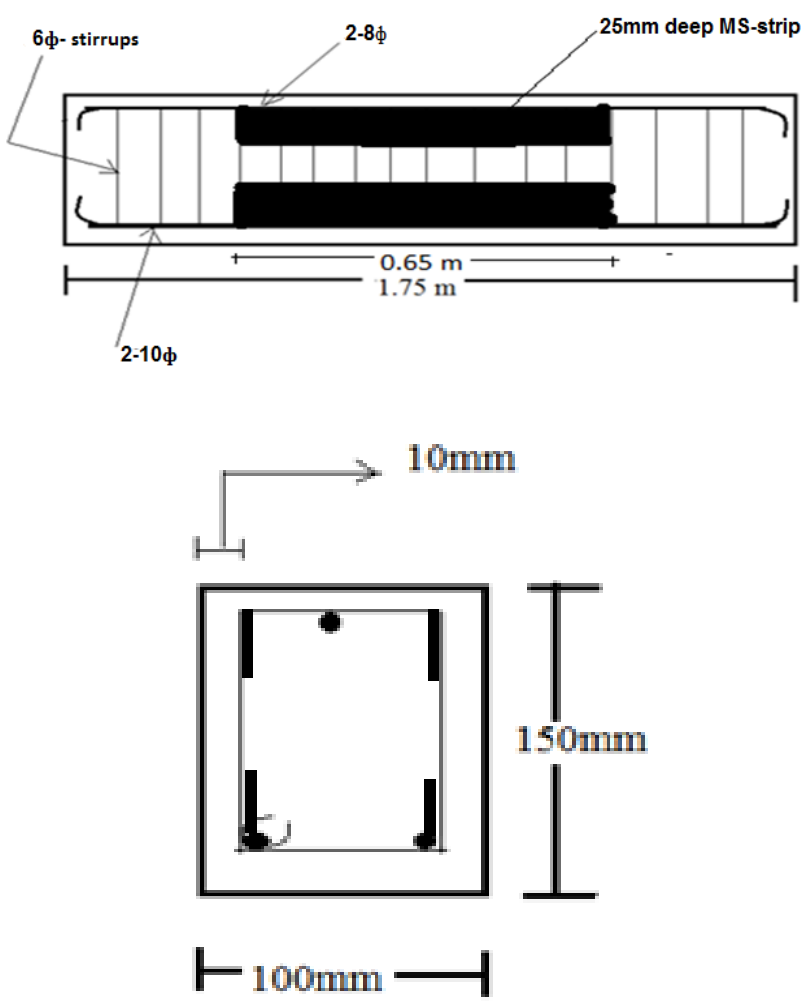

Fig -3: Composite RCC beam with MS-strips in central part above \& below NA (L/3)

\section{TESTING METHODOLOGY}

An experimental program was undertaken to verify the proposed design procedure and to calibrate future analytical studies. The twelve ( 3 of each type) full-scale beam specimens were instrumented for deflection and load measurements. Each specimen was tested to failure in the NIT Srinagar Structural Testing Laboratory. The beams were tested under loading frame and concrete cubes were tested under UTM. This section gives an overview of the experimental program including details of the instrumentation and data acquisition.

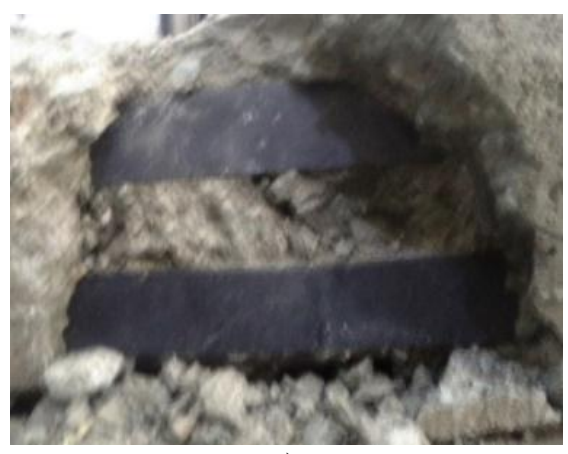

a) 


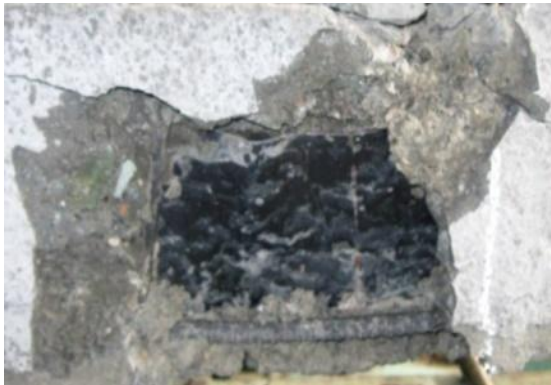

b)

Fig -4: MS strips embedded in beam

\subsection{Loading Test Frame and Data Acquisition}

The most important part of instrumentation is the loading frame made of structural steel columns and I-sections. The capacity of loading-frame is $500 \mathrm{KN}$. Specimens were set up with loading at one-third positions of a beam. A picture of the loading frame is shown in Fig -5. The vertical load is provided with the help of a hydraulic jack and the pumping unit, where as the load is to be measured with the help of proving ring attached to the pumping assembly and loading frame. $50 \mathrm{KN}$ proving ring with a least count of $0.84 \mathrm{KN}$ was used to calculate the load and the deflection caused was measured with the help of dial gauge kept below the beam at Central position, with a least count of $0.0254 \mathrm{~mm}$. The vertical load is measured in $\mathrm{KN}$ and the deflection is measured in $\mathrm{mm}$ from the dial gauge. The load is applied in regular intervals at a uniform rate; and deflection is calculated accordingly. This continues till the ultimate load is achieved and failure of the test specimen occurs.

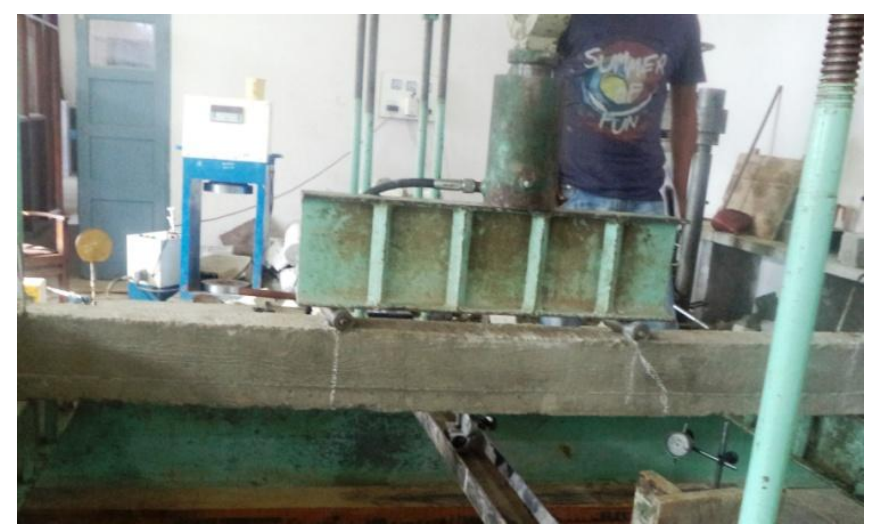

a)

Fig-5: Beam testing

\subsection{Testing Arrangement}

The testing of beam is to be done as per --- ASTM-D6272 All the twelve beams were tested under simply supported end conditions. Four point bending test was adopted for testing, because it ensures pure flexure behavior at the central part of the beam. Out of these twelve beams three are control beams, which are tested after 28 days of curing to find out the ultimate load carrying capacity and the maximum deflection at failure. Subsequently the remaining nine beams, three of each type are tested in the same manner as of control beam and the test results of each specimen were compared. All the beams were tested in house on loading frame at Structural Engineering Laboratory in Civil Engineering Department at National Institute of Technology, Srinagar.

\section{RESULTS AND DISCUSSION}

In this section a brief introduction about the material used in the project and their engineering properties are given, as obtained from the test results. From test results of beams, load-vs-deflection curves for all types of beams are drawn. The final results of all the beams are compared and thoroughly studied. Different parameters like deflection, stiffness, strength etc were taken under consideration to check the feasibility of the project. The crack pattern in beams was also studied and appropriate conclusions were drawn keeping in view the serviceability criteria.

\subsection{Material and their Properties}

The materials used in this project were cement, fine aggregates, coarse aggregates, steel bars, mild-steel sheets and binding wires. The various engineering properties of all the materials are obtained from testing of materials.

\subsubsection{Cement}

Cement acts as binding material in concrete, which binds coarse aggregates and fine aggregates. The properties of cement affects the strength of concrete. The cement used was 43-Grade (IS 8112). The standard consistency of cement used was $30.34 \%$ with a fineness of $3 \%$.

\subsubsection{Coarse and Fine Aggregates}

Sand is usually used as fine aggregate after it is cleaned and rendered free from silt clay and other impurities. The testing of sand is necessary in order to check its engineering properties. $1 \mathrm{~kg}$ of sand was taken and sieve analysis was done to obtain zone of sand (zone-II), which gives us an indication about its compatibility. Coarse aggregates form about $75 \%$ of concrete of nominal mix M20. Gravel and crushed rock are normally used as coarse aggregate, the maximum size of coarse aggregate to be used in RCC work depends on thickness of member and space available around reinforcing bar. As the size of specimens is small so the aggregate size taken is about $8-10 \mathrm{~mm}$.

\subsubsection{Steel Bars and MS Sheets}

Concrete is reinforced with steel primarily to make up for concrete's incapability for tensile resistance. Steel imparts ductility to a material that is otherwise brittle. The steel used in this project was $\mathrm{Fe}-415$ and $\mathrm{Fe}-250$ of nominal diameter of $6 \mathrm{~mm}, 8 \mathrm{~mm}$ and $10 \mathrm{~mm}$.

MS sheet is used as a composite material in order to increase the stiffness of beam. 
Table -1: Physical Properties of MS-Sheets

\begin{tabular}{|l|l|l|l|}
\hline $\begin{array}{l}\mathrm{Sr} \\
\text { No. }\end{array}$ & $\begin{array}{l}\text { Properties Of } \\
\text { MS-Sheets }\end{array}$ & $0.5 \mathrm{~mm}$ thick & $1 \mathrm{~mm}$ thick \\
\hline 1 & Gauge & 25 & 19 \\
\hline 2 & Density & $7850 \mathrm{~kg} / \mathrm{m}^{3}$ & $7850 \mathrm{~kg} / \mathrm{m}^{3}$ \\
\hline 3 & $\begin{array}{l}\text { Modulus of } \\
\text { elasticity }\end{array}$ & $2 * 10^{5} \mathrm{MPa}$ & $2 * 10^{5} \mathrm{MPa}$ \\
\hline 4 & Poison ratio & 0.3 & 0.3 \\
\hline 5 & $\begin{array}{l}\text { Ultimate } \\
\text { strength }\end{array}$ & $410 \mathrm{MPa}$ & $410 \mathrm{MPa}$ \\
\hline 6 & Yield strength & $250 \mathrm{MPa}$ & $250 \mathrm{MPa}$ \\
\hline
\end{tabular}

\subsection{Observation of Results}

In this section load-vs-deflection curve of all beams are plotted. The curves of all beams are compared and thoroughly studied, and various conclusions are drawn

\subsubsection{Normal Beam $(\mathrm{CB})$}

Table -2: Experimental observations of CB

\begin{tabular}{|c|c|c|c|}
\hline $\begin{array}{l}\text { Reading of } \\
\text { proving } \\
\text { ring(div) }\end{array}$ & $\begin{array}{l}\text { Applied } \\
\text { load on } \\
\text { beam } \\
(\mathrm{KN})\end{array}$ & $\begin{array}{l}\text { Reading of } \\
\text { Centre dial } \\
\text { gauge } \\
\text { (div) }\end{array}$ & $\begin{array}{l}\text { Deflection at } \\
\text { centre }(\mathrm{mm})\end{array}$ \\
\hline 1 & 0.84 & 8 & 0.2032 \\
\hline 3 & 2.52 & 16 & 0.4064 \\
\hline 5 & 4.2 & 25 & 0.635 \\
\hline 7 & 5.88 & 42 & 1.0668 \\
\hline 9 & 7.56 & 65 & 1.651 \\
\hline 11 & 9.24 & 87 & 2.2098 \\
\hline 12 & 10.08 & 100 & 2.54 \\
\hline 15 & 12.6 & 133 & 3.3782 \\
\hline 17 & 14.28 & 153 & 3.8862 \\
\hline 19 & 15.96 & 179 & 4.5466 \\
\hline 21 & 17.64 & 200 & 5.08 \\
\hline 23 & 19.32 & 222 & 5.6388 \\
\hline 24 & 20.16 & 235 & 5.969 \\
\hline 25 & 21 & 248 & 6.2992 \\
\hline 26 & 21.84 & 259 & 6.5786 \\
\hline 27 & 22.68 & 266 & 6.7564 \\
\hline 30 & 25.2 & 300 & 7.62 \\
\hline 32 & 26.88 & 325 & 8.255 \\
\hline 30 & 25.2 & 340 & 8.636 \\
\hline 28 & 23.52 & 360 & 9.144 \\
\hline
\end{tabular}

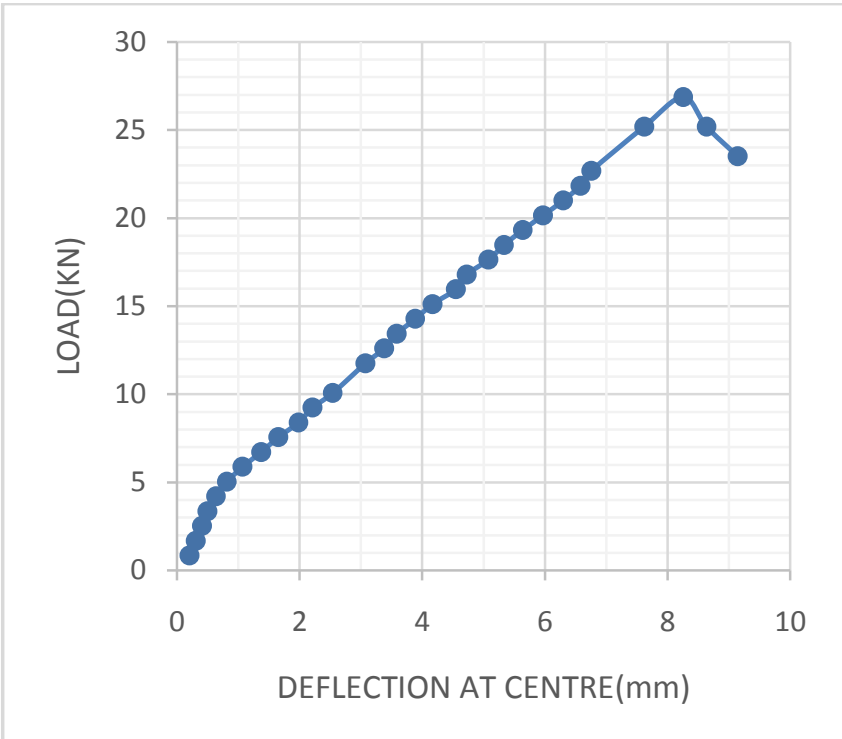

Graph -1: load vs deflection curve of CB

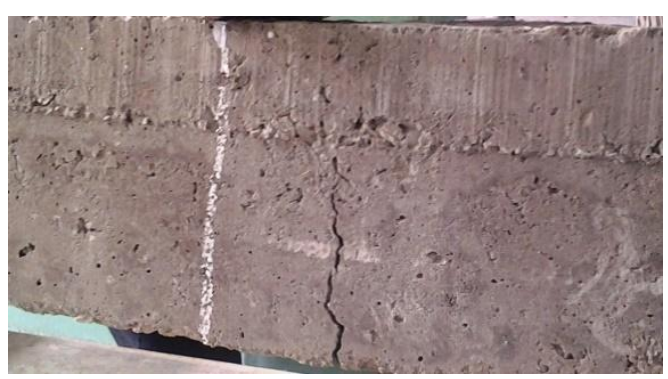

a)

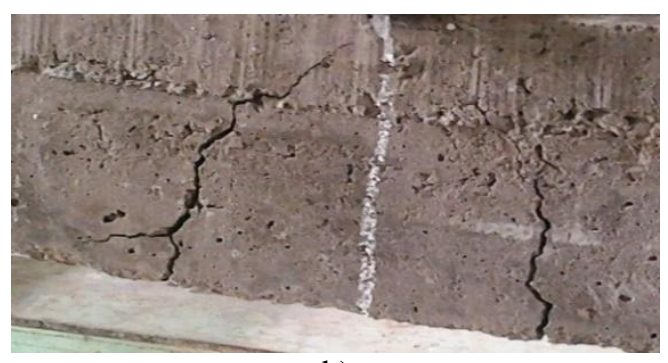

b)

Fig -6: crack pattern in CB (a) Initial crack near centre (b) Crack propagation

\subsubsection{Beam with 0.5mm MS Strip on Full Face (T-1)}

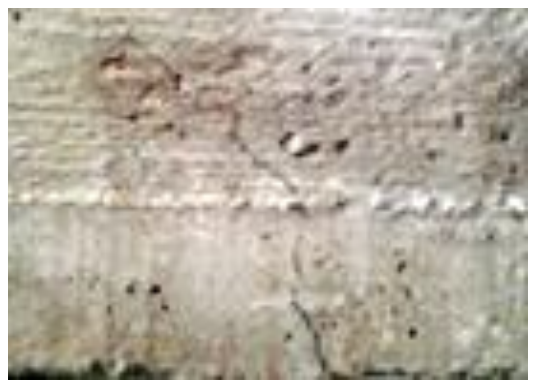

a) 


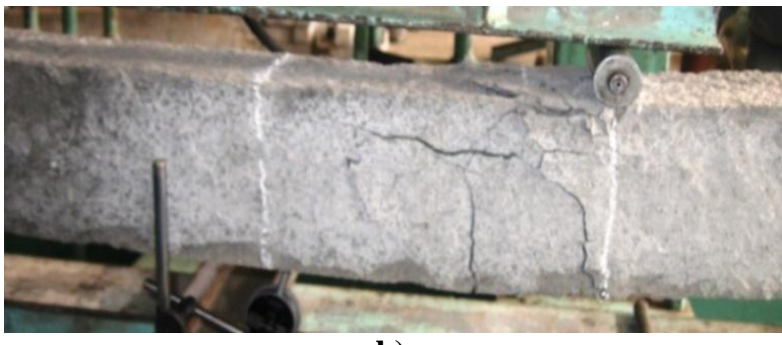

b)

Fig -7: crack pattern in beam T-1 (a) Intial crack near centre (b) Crack at collapse

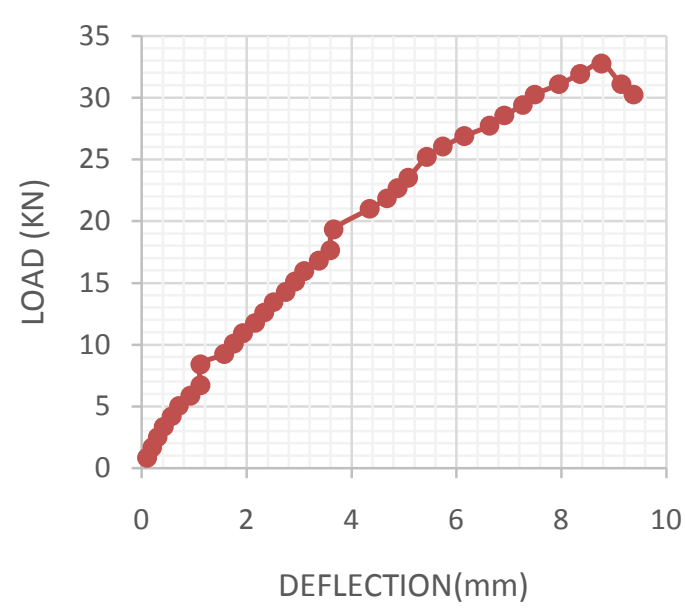

Graph -2: load vs deflection curve of beam T-1

Table -3: Experimental observation of T-1

\begin{tabular}{|l|l|l|l|}
\hline $\begin{array}{l}\text { proving } \\
\text { ring } \\
\text { reading }\end{array}$ & $\begin{array}{l}\text { Load( } \\
\text { KN) }\end{array}$ & $\begin{array}{l}\text { dial gauge } \\
\text { reading(div) }\end{array}$ & $\begin{array}{l}\text { Def. at } \\
\text { centre(mm) }\end{array}$ \\
\hline 1 & 0.84 & 4 & 0.1016 \\
\hline 2 & 1.68 & 8 & 0.2032 \\
\hline 3 & 2.52 & 12 & 0.3048 \\
\hline 4 & 3.36 & 16.5 & 0.4191 \\
\hline 5 & 4.2 & 22.5 & 0.5715 \\
\hline 6 & 5.04 & 28 & 0.7112 \\
\hline 8 & 6.72 & 44 & 1.1176 \\
\hline 10 & 8.4 & 44 & 1.1176 \\
\hline 12 & 10.08 & 69 & 1.7526 \\
\hline 13 & 10.92 & 76 & 1.9304 \\
\hline 15 & 12.6 & 92 & 2.3368 \\
\hline 17 & 14.28 & 108 & 2.7432 \\
\hline 18 & 15.12 & 115 & 2.921 \\
\hline 20 & 16.8 & 133 & 3.3782 \\
\hline 21 & 17.64 & 141.5 & 3.5941 \\
\hline 23 & 19.32 & 144 & 3.6576 \\
\hline 26 & 21.84 & 184 & 4.6736 \\
\hline 27 & 22.68 & 192 & 4.8768 \\
\hline 30 & 25.2 & 214 & 5.4356 \\
\hline 32 & 26.88 & 242 & 6.1468 \\
\hline 33 & 27.72 & 261 & 6.6294 \\
\hline & & & \\
\hline
\end{tabular}

\begin{tabular}{|l|l|l|l|}
34 & 28.56 & 272 & 6.9088 \\
\hline 35 & 29.4 & 286 & 7.2644 \\
\hline 36 & 30.24 & 295 & 7.493 \\
\hline 37 & 31.08 & 313 & 7.9502 \\
\hline 38 & 31.92 & 329 & 8.3566 \\
\hline 39 & 32.76 & 345 & 8.763 \\
\hline 37 & 31.08 & 360 & 9.144 \\
\hline 36 & 30.24 & 375 & 9.375 \\
\hline
\end{tabular}

\subsubsection{Beam with 1mm MS strip on Full Face (T-2)}

Table -4: Experimental observations of beam T-2

\begin{tabular}{|l|l|l|l|}
\hline $\begin{array}{l}\text { Proving } \\
\text { ring } \\
\text { reading }\end{array}$ & Load(KN) & $\begin{array}{l}\text { dial gauge } \\
\text { reading } \\
\text { (div) }\end{array}$ & $\begin{array}{l}\text { Deflection } \\
\text { at } \\
\text { centre(mm) }\end{array}$ \\
\hline 1 & 0.84 & 4.5 & 0.1143 \\
\hline 3 & 2.52 & 12 & 0.3048 \\
\hline 6 & 5.04 & 32 & 0.8128 \\
\hline 9 & 7.56 & 47 & 1.1938 \\
\hline 12 & 10.08 & 62 & 1.5748 \\
\hline 15 & 12.6 & 82 & 2.0828 \\
\hline 18 & 15.12 & 101 & 2.5654 \\
\hline 21 & 17.64 & 117 & 2.9718 \\
\hline 24 & 20.16 & 138 & 3.5052 \\
\hline 27 & 22.68 & 157 & 3.9878 \\
\hline 30 & 25.2 & 177 & 4.4958 \\
\hline 34 & 28.56 & 207 & 5.2578 \\
\hline 35 & 29.4 & 215 & 5.461 \\
\hline 36 & 30.24 & 215 & 5.461 \\
\hline 38 & 31.92 & 237 & 6.0198 \\
\hline 39 & 32.76 & 244 & 6.1976 \\
\hline 41 & 34.44 & 257 & 6.5278 \\
\hline 43 & 36.12 & 275 & 6.985 \\
\hline 45 & 37.8 & 290 & 7.366 \\
\hline 47 & 39.48 & 307 & 7.7978 \\
\hline 48 & 40.32 & 320 & 8.128 \\
\hline 50 & 42 & 337 & 8.5598 \\
\hline 51 & 42.84 & 352 & 8.9408 \\
\hline 52 & 43.68 & 367 & 9.3218 \\
\hline 49 & 41.16 & 390 & 9.906 \\
\hline 47 & 39.48 & 410 & 10.414 \\
\hline & & & \\
\hline 15 & & \\
\hline 35 & & \\
\hline
\end{tabular}




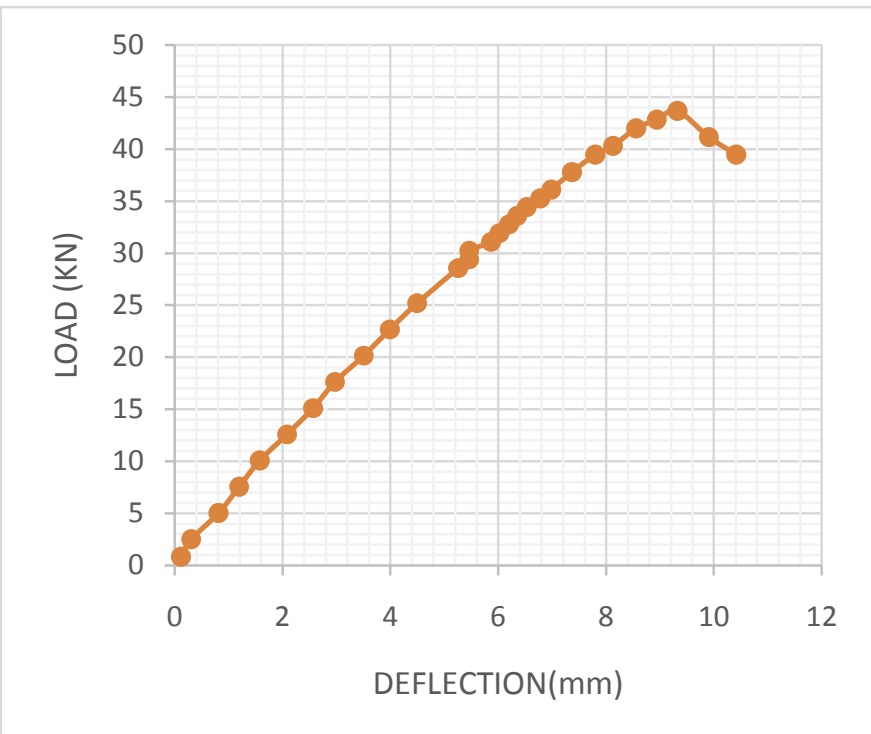

Graph -3: load vs deflection curve of beam T-2

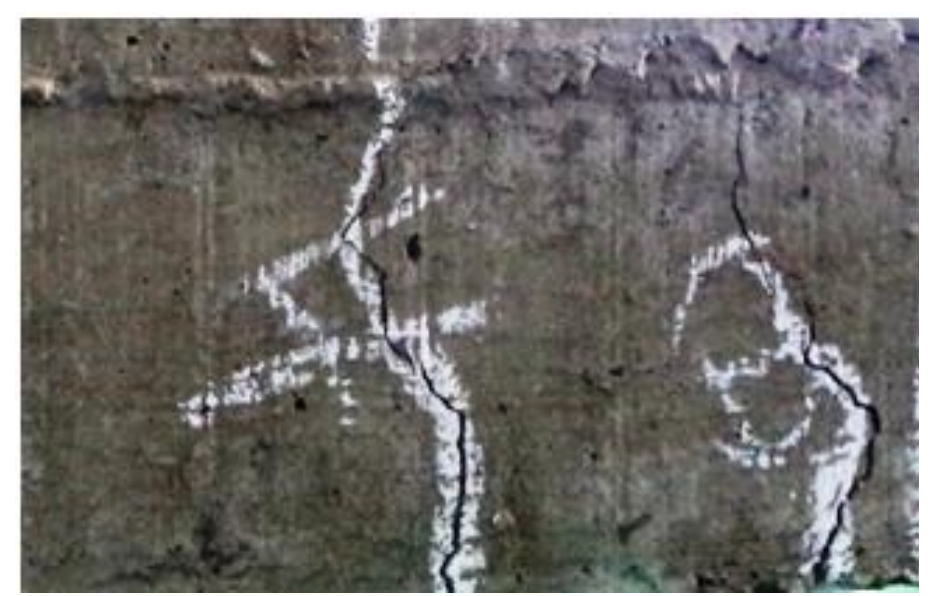

Fig -8: crack pattern and propagation in beam T-2

\subsubsection{Beam with 1mm MS Strips above and below}

\section{Neutral Axis (Central Part) - T3}

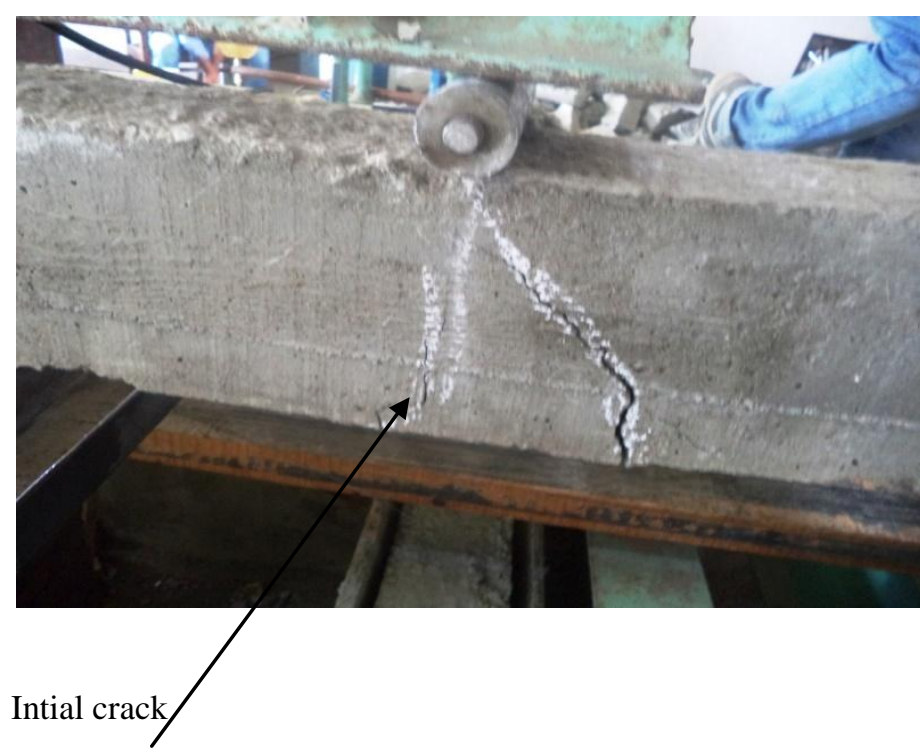

Fig -9: crack pattern in T-3 beam

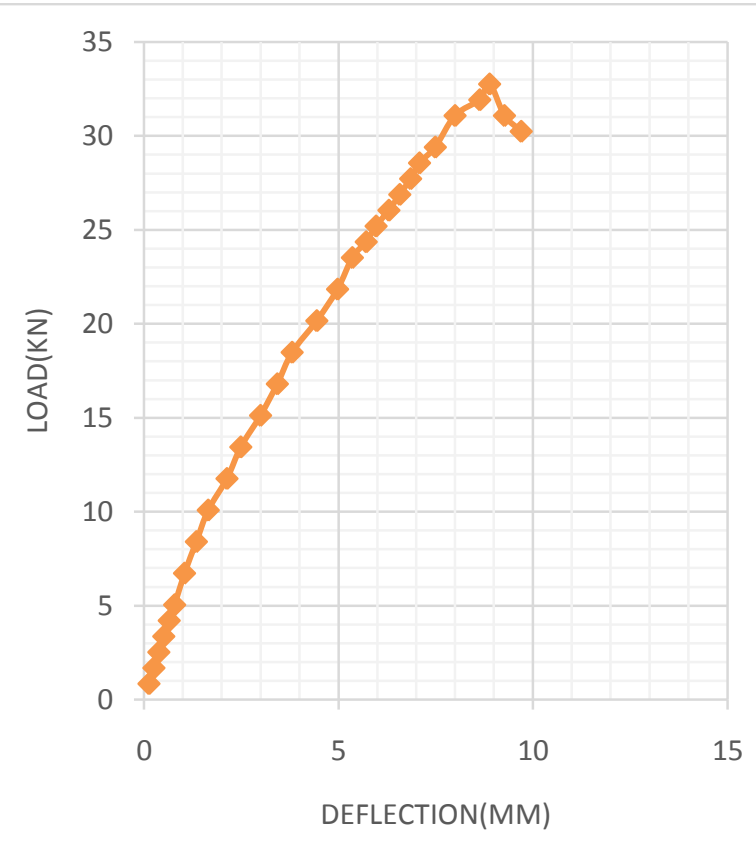

Graph -4: load vs deflection curve of T-3 beam

Table -5: Experimental observations of beam T-3

\begin{tabular}{|c|c|c|c|}
\hline $\begin{array}{l}\text { P.R. } \\
\text { Readin } \\
\text { gs } \\
\end{array}$ & $\begin{array}{l}\operatorname{Load}(\mathrm{KN} \\
)\end{array}$ & $\begin{array}{l}\text { D.G. } \\
\text { Reading }\end{array}$ & $\begin{array}{l}\text { Deflection } \\
(\mathrm{mm})\end{array}$ \\
\hline 1 & 0.84 & 5 & 0.127 \\
\hline 3 & 2.52 & 15 & 0.381 \\
\hline 5 & 4.2 & 25.5 & 0.6477 \\
\hline 8 & 6.72 & 41 & 1.0414 \\
\hline 10 & 8.4 & 53 & 1.3462 \\
\hline 12 & 10.08 & 65 & 1.651 \\
\hline 14 & 11.76 & 84 & 2.1336 \\
\hline 16 & 13.44 & 98 & 2.4892 \\
\hline 18 & 15.12 & 118 & 2.9972 \\
\hline 20 & 16.8 & 135 & 3.429 \\
\hline 22 & 18.48 & 150 & 3.81 \\
\hline 24 & 20.16 & 175 & 4.445 \\
\hline 26 & 21.84 & 196 & 4.9784 \\
\hline 28 & 23.52 & 211 & 5.3594 \\
\hline 30 & 25.2 & 235 & 5.969 \\
\hline 31 & 26.04 & 248 & 6.2992 \\
\hline 32 & 26.88 & 259 & 6.5786 \\
\hline 33 & 27.72 & 270 & 6.858 \\
\hline 34 & 28.56 & 279 & 7.0866 \\
\hline 35 & 29.4 & 295 & 7.493 \\
\hline 37 & 31.08 & 315 & 8.001 \\
\hline 38 & 31.92 & 340 & 8.636 \\
\hline 39 & 32.76 & 350 & 8.89 \\
\hline 37 & 31.08 & 365 & 9.271 \\
\hline 36 & 30.24 & 382 & 9.7028 \\
\hline
\end{tabular}




\subsection{Comparison of Results}

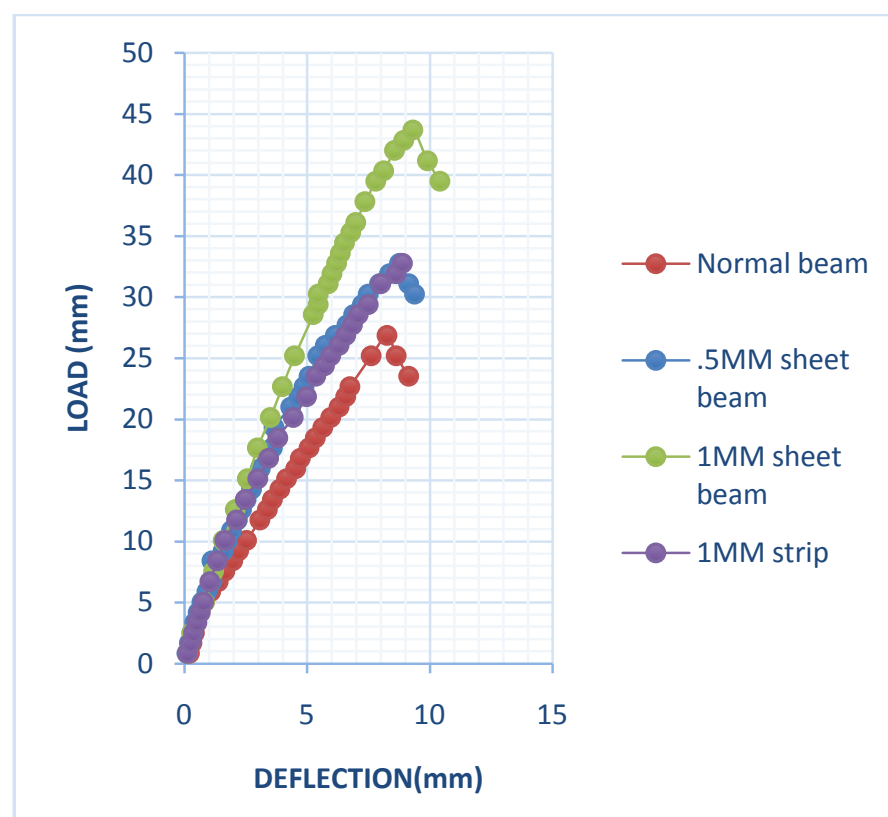

Graph -5: load vs deflection curve of all beams

Table -6: comparison of results of all beams

\begin{tabular}{|l|l|l|l|l|}
\hline S.No. & $\begin{array}{l}\text { Type } \\
\text { of } \\
\text { Beam }\end{array}$ & $\begin{array}{l}\text { Load } \\
(\mathrm{KN})\end{array}$ & $\begin{array}{l}\text { Deflection } \\
\text { at centre } \\
(\mathrm{mm})\end{array}$ & Remarks \\
\hline 1 & CB & 26.88 & 8.255 & - \\
\hline 2 & T-1 & 26.88 & 6.53 & $\begin{array}{l}\text { Load carrying } \\
\text { capacity and } \\
\text { increases control } \\
\text { sufficient } \\
\text { in deflection }\end{array}$ \\
\hline 3 & T-2 & 26.88 & 4.98 & $\begin{array}{l}\text { Load carrying } \\
\text { capacity higher } \\
\text { increases hes and } \\
\text { than that of beam } \\
\text { T-1 in } \\
\text { remarkable } \\
\text { control } \\
\text { deflection. }\end{array}$ \\
\hline 4 & T-3 & 26.88 & 6.576 & $\begin{array}{l}\text { Almost same } \\
\text { behavior as that } \\
\text { of beam T-1 }\end{array}$ \\
\hline
\end{tabular}

From the initial portion of graph, the behaviour of all beams is same which indicates that intial load is carried by concrete. After this, graph of composite beams shows increase in slope than normal beam indicating that composite beam carries more load and shows less deflection, therefore it can be concluded that the stiffness of composite beam has increased. Moreover, the beam with $1 \mathrm{~mm}$ strip has maximum slope as compared to other beams indicating that the stiffness of the beam increases by increasing thickness of MS strips. Also the graph of T-1 and T-3 shows almost same behaviour which shows the effect of depth of sheet in deflection control.

\subsection{Comparison between Beam T-1 and T-3}

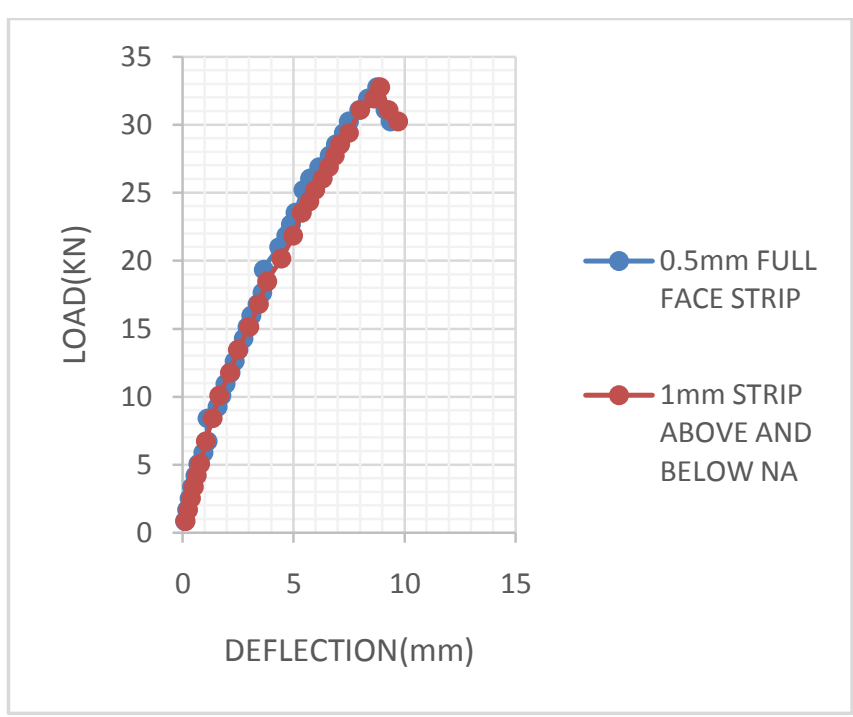

Graph -6: load vs deflection curve of T-1 \& T-3

From the above graph the following conclusion are obtained:

\subsubsection{Deflection Control}

\begin{tabular}{|l|l|l|l|l|}
\hline S.no & $\begin{array}{l}\text { load } \\
(\mathrm{KN})\end{array}$ & $\begin{array}{l}\text { Deflection } \\
\text { in beam T- } \\
1(\mathrm{~mm})\end{array}$ & $\begin{array}{l}\text { Deflection } \\
\text { in beam T-3 } \\
(\mathrm{mm})\end{array}$ & Remarks \\
\hline 1. & 27 & 6.15 & 6.85 & $\begin{array}{l}\text { Load at } \\
\text { intial crack } \\
\text { of both T-1 } \\
\text { \&T-2. }\end{array}$ \\
\hline
\end{tabular}

From the above data it is clear that the deflection at a particular load is slightly more in beamT-3 as compared to $\mathrm{T}-1$. The stiffness is $4.39 \mathrm{KN} / \mathrm{mm}$ and $3.94 \mathrm{KN} / \mathrm{mm}$ for $\mathrm{T}-1$ and $\mathrm{T}-3$ respectively. This indicates the depth of strip affects the stiffness more.

\subsubsection{Load Carrying Capacity}

\begin{tabular}{|l|l|l|l|}
\hline S.no & Beam & $\begin{array}{l}\text { Max. } \\
\text { deflection } \\
(\mathrm{mm})\end{array}$ & $\begin{array}{l}\text { Load } \\
(\mathrm{KN})\end{array}$ \\
\hline 1. & $\mathrm{~T}-1$ & 8.763 & 32.76 \\
\hline 2. & $\mathrm{~T}-3$ & 8.89 & 32.76 \\
\hline
\end{tabular}

From the above data it is clear that the load carrying capacity of both T-1 and T-3 is same. This indicates that the strip is more effective and economical at central position.

\section{CONCLUSIONS}

By comparing the test results of control beam and test beams we conclude;

$>$ Deflection control

- By using $0.5 \mathrm{~mm}$ thick MS-strip (full face) deflection is controlled by $28 \%$ as compared to normal beam. 
- By using $1 \mathrm{~mm}$ thick MS-strip (full face) deflection is controlled by $42 \%$ as compared to normal beam.

- $\quad$ By using $1 \mathrm{~mm}$ thick MS-strip (above and below neutral axis) deflection is controlled by $22 \%$ as compared to normal beam.

$>$ Strength

- $\quad$ Strength is increased by $22 \%$ as compared to control beam by using $0.5 \mathrm{~mm}$ thick MS-strip.

- $\quad$ Strength is increased by $62 \%$ as compared to control beam by using $1 \mathrm{~mm}$ thick MS-strip.

- $\quad$ Strength is increased by $22 \%$ by using $1 \mathrm{~mm}$ thick MS-strip (above and below NA)

\section{Stiffness}

- $\quad$ Stiffness is increased by $38 \%$ by introducing $0.5 \mathrm{~mm}$ thick MS-strip along full face.

- $\quad$ Stiffness is increased by $72 \%$ by introducing $1 \mathrm{~mm}$ thick MS-strip along full face.

- $\quad$ Stiffness is increased by $29.5 \%$ by introducing $0.5 \mathrm{~mm}$ thick MS-strip above \& below NA

$>$ Introduction of MS-sheet increases the ductility of beam.

$>$ MS-sheet also acts as shear reinforcement.

$>$ Weight of a composite structure is quite low as compared to normal R.C.C structure thus economical.

$>\quad$ The maximum shear force and maximum bending moment are less in composite beam as compared to RCC beam

$>$ The introduction of strip at central position is more effective and economical.

\section{FUTURE SCOPE AND LIMITATION}

As the results show considerable increase not only in the required property i.e. stiffness of beam, but also in various other properties like strength, durability etc. Engineers are always in search of enhancing these properties. Increasing the stiffness of beam in order to control deflection by this process can be widely used where depth is constrain i.e. like in shallow beams, for aesthetical importance etc. helps in reducing section of beam. It also acts as shear reinforcement hence preventing shear failure. The MS-sheets are available in varying thickness which increases the flexibility of this project. Modifications can be done as per the requirement to achieve the required results. Some of these are as under

a) Vary the thickness of MS-sheets.

b) Provide shear connectors for proper bonding

c) Provide perforated MS-sheets

d) Varying number of MS-sheets.

As yielding of MS-sheet did not take place it suggest that full strength of MS-sheet is not achieved which is the main limitation of this method. Also the bond between sheet and concrete is weak.

\section{ACKNOWLEDGEMENTS}

"It is not possible to complete any project without the assistance and encouragement of other person. This one is certainly no exception".On the onset of this report, we would like to express our sincere and heartfelt obligation towards some of the personage who really helped us in this project. We are ineffable indebted to Dr. J.A. BHAT (Prof), Department Of Civil Engineering, N.I.T Srinagar for his patient guidance, constant supervision, enthusiastic encouragement as well as for providing us necessary information regarding this project and also for his support in completing the project. Special thanks to our parents.

\section{REFERENCES}

[1]. ASTM D6272 -10, Standard Test Method for Flexural Properties of Unreinforced and Reinforced Plastics and Electrical Insulating Materials by Four-Point Bending.

[2]. ACI 435-95 (Control of deflection in concrete structure) reported by ACI Committee 435

[3]. C.C.Wang,- (Strength of concrete encased composite construction member, journal of structural engineering volume-127)

[4]. IS: 456(2000), - Indian Standard Code of Practice for Plan and Reinforcement concrete (Fourth Revisions), Bureau of Indian Standards (BIS), New Delhi.

[5]. IS:8112(2013)- Indian standard ordinary Portland cement 43 Grade-specification (2nd revision)

[6]. IS: 383(1970) -Specification for coarse and fine aggregate from natural sources for concrete (Second revision).

[7]. IS:2386(part I)-1963,-Indian standard method of test for aggregate for concrete, part I particle size and shape

[8]. Jack C,McCormac, ("Design of reinforced concrete ", 2nd Edition) publication "Harper \& row"

[9]. Shashikala, Koppad, Dr. S.V.Itti, "Comparative Study of RCC and Composite Multistoreyed Buildings" International Journal of Engineering and Innovative Technology (IJEIT), ISSN: 2277-3754,Volume 3, Issue 5, November 2013.

[10]. S Unikrishna Pillai/Devdas Menon,("Reinforced Concrete Design", 3rd Edition) Publication, TATA McGraw Hill.

[11]. Structural Engineering Report MUST-98-1 (Strengthening Existing Reinforced Concrete Beams for Flexure Using Bolted External Structural Steel Channels) by Christopher M. Foley and Evan R. Buckhouse January 1998

\section{BIOGRAPHIES}

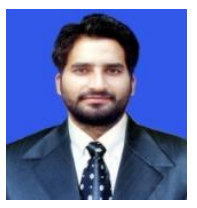

Asif Reyaz, B.Tech. in civil engineering, NIT Srinagar, J\&K India- (2010-14) current status: lecturer at Satya College of Engg. Mitrol Haryana Add: near dc office pulwama J\&K, india - $192301 \quad$ Email: naikasif003@gmail.com

Phone no: +919419026623 
Mohmad Mohsin Thakur, B.Tech. in civil engineering, NIT Srinagar, J\&K India(2010-14) current status: MTech in geotechnical Engg. at IIT-gandhinagar Add: lasjan byepass Srinagar, J\&K India-191101

Email:mohsintthkr8@gmail.com

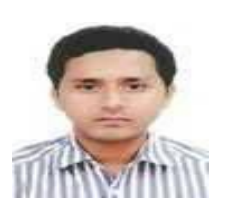

Ali, B.Tech. in civil engineering, NIT Srinagar, J\&K India.-(2010-14) Add: nawada bihar india-805101

Email: malik.nwd@gmail.com

Ishtiyak Ahmad, B.Tech. in civil engineering, NIT Srinagar, J\&K India(2010-14) Add: hamdan-abad kishtwar J\&K, india -182204

Email: Ishtiyaqahmad201@gmail.com 